\title{
Laboratory Investigations in Support of Carbon Dioxide-in-Water Emulsions Stabilized by Fine Particles for Ocean and Geologic Sequestration of Carbon Dioxide (Former Title: Laboratory Investigations in Support of Carbon Dioxide-Limestone Sequestration in the Ocean)
}

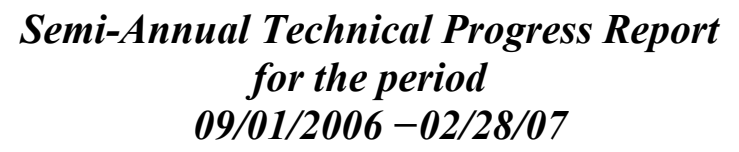

Dan Golomb, David Ryan, Eugene Barry Co-Principal Investigators

Stephen Pennell

Faculty Advisor

Peter Swett, Michael Woods, Tom Lawlor

Research Assistants

March 2007

Submitted to

US Department of Energy

National Energy Technology Laboratory

Dr. Heino Beckert

Project Officer

Co-operative Agreement DE-FC26-02NT41441

UML Project ST-105691

University of Massachusetts Lowell, Lowell, MA 01854 


\section{DISCLAIMER}

This report was prepared as an account of work sponsored by an agency of the United States Government. Neither the United States Government nor any agency thereof, nor any of their employees, makes any warranty, express or implied, or assumes any legal liability or responsibility for the accuracy, completeness, or usefulness of any information, apparatus, product, or process disclosed, or represents that its use would not infringe privately owned rights. Reference herein to any specific commercial product, process, or service by trade name, trademark, manufacturer, or otherwise does not necessarily constitute or imply its endorsement, recommendation, or favoring by the United States Government or any agency thereof. The views and opinions of authors expressed herein do not necessarily state or reflect those of the United States government or any agency thereof. 


\title{
Laboratory Investigations in Support of Carbon Dioxide-in-Water Emulsions Stabilized by Fine Particles for Ocean and Geologic Sequestration of Carbon Dioxide
}

\begin{abstract}
Since the submission of our last Semi-annual Report, dated September 2006, the research objectives of this Co-operative Agreement shifted toward geologic sequestration of carbon dioxide. In the period September 2006 - February 2007, experiments were conducted in a High-Pressure Batch Reactor (HPBR) for creating emulsions of liquid carbon dioxide $\left(\mathrm{CO}_{2}\right)$-in-water stabilized by fine particles for geologic sequestration of $\mathrm{CO}_{2}$. Also, emulsions were created in water of a binary mixture of liquid carbon dioxide and liquid hydrogen sulfide $\left(\mathrm{lH}_{2} \mathrm{~S}\right)$, called Acid Gas (AG). This leads to the possibility of safe disposal of $A G$ in deep geologic formations, such as saline aquifers. The stabilizing particles included pulverized limestone $\left(\mathrm{CaCO}_{3}\right)$, unprocessed flyash, collected by an electrostatic precipitator at a local coal-fired power plant, and pulverized siderite $\left(\mathrm{FeCO}_{3}\right)$. Particle size ranged from submicron to a few micrometers.

The first important finding is that $l \mathrm{CO}_{2}$ and $l \mathrm{H}_{2} \mathrm{~S}$ freely mix as a binary liquid without phase separation. The next finding is that the mixture of $l \mathrm{CO}_{2}$ and $l \mathrm{H}_{2} \mathrm{~S}$ can be emulsified in water using fine particles as emulsifying agents. Such emulsions are stable over prolonged periods, so it should not be a problem to inject an emulsion into subterranean formations. The advantage of injecting an emulsion into subterranean formations is that it is denser than the pure liquid, therefore it is likely to disperse in the bottom of the geologic formation, rather than buoying upward (called fingering). In such a fashion, the risk of the liquids escaping from the formation, and possibly re-emerging into the atmosphere, is minimized. This is especially important for $\mathrm{H}_{2} \mathrm{~S}$, because it is a highly toxic gas. Furthermore, the emulsion may interact with the surrounding minerals, causing mineral trapping. This may lead to longer sequestration periods than injecting the pure liquids alone.
\end{abstract}




\section{TABLE OF CONTENTS}

ABSTRACT $c$ page

1. Experimental 5

1.1 Materials $\quad 5$

1.2 Apparatus $\quad 5$

2. Results 6

2.1. Liquid Carbon Dioxide and Pulverized Limestone 6

2.2. Liquid Acid Gas and Pulverized Limestone 6

2.3. Liquid Acid Gas and Flyash $\quad 6$

2.4. Liquid Acid Gas and Siderite $\quad 7$

$\begin{array}{ll}\text { CONCLUSIONS } & 7\end{array}$

PLANS FOR THE NEXT PERIOD $\quad 8$

\section{FIGURES}

Figure 1. High Pressure Batch Reactor with View Window and Auxiliary

Equipment

Figure 2. Emulsion of $\mathrm{ICO}_{2}$-in-Water Stabilized with Pulverized Limestone

Figure 3. Emulsion of IAG-in-Water Stabilized with Sigma-Aldrich reagent grade $\mathrm{CaCO}_{3}$

Figure 4. Emulsion of IAG-in-Water Stabilized with Flyash

Figure 5. Emulsion of IAG-in-Water Stabilized with Siderite 


\section{EXPERIMENTAL}

\subsection{Materials}

Limestone. Mined pulverized limestone $\left(96.5 \% \mathrm{CaCO}_{3}, 2 \% \mathrm{MgCO}_{3}, 1 \%\right.$ silica and silicates, $0.5 \%$ others) supplied by Huber Engineered Materials, Quincy, IL, was used having a bulk specific gravity of 2.7 and a solubility of $0.0035 \mathrm{~g} / 100 \mathrm{~mL} \mathrm{H} \mathrm{H}_{2} \mathrm{O}$ at $100^{\circ} \mathrm{C}$. The pulverized samples can be purchased with different size distributions. In this study, Hubercarb ${ }^{\mathrm{TM}}$ Q6 with a supplier quoted median particle size of $5.5 \mu \mathrm{m}$ was used.

Flyash. Flyash collected by an electrostatic precipitator (ESP) at the Salem Harbor, Massachusetts, coal-fired power plant was used without further processing. From Scanning Electron Microscopy, a mean particle diameter of $2.5 \mu \mathrm{m}$ was determined. EDX analysis shows the major elements in flyash are $\mathrm{Si}$ and $\mathrm{Al}$, with minor elements $\mathrm{Ca}, \mathrm{Fe}$ and $\mathrm{Mg}$, and trace elements $\mathrm{K}, \mathrm{S}$ and Ti.

Siderite. A piece of siderite mineral $\left(\mathrm{FeCO}_{3}\right)$ was milled into fine powder in a rotary pulverizer using hardened steel plates, then sieved through a U.S. mesh 325 sieve. About $200 \mathrm{~g}$ of the powder and $500 \mathrm{~mL}$ of water was further milled in a Patterson-Kelley V-shaped wet/dry blender charged with $200 \mathrm{~g}$ of approximately $1 \mathrm{~cm}$ silicon nitride grinding pebbles. After about 24 hours, the pulverized siderite was recovered by Buchner filtration, and the filter cake was air-dried. We have not directly determined the particle size, but by analogy to previously used milled beach sand, the mean particle size should be in the $3-4 \mu \mathrm{m}$ range.

\subsection{Apparatus}

The investigations of the formation and properties of particle stabilized $\mathrm{CO}_{2}$-in-water $(\mathrm{C} / \mathrm{W})$ and $\mathrm{AG}$-in-water $(\mathrm{A} / \mathrm{W})$ emulsions were performed in a High-Pressure Batch Reactor (HPBR) with view windows. The reactor, the auxiliary equipment for introducing the reactants into the reactor, and the monitoring instruments are depicted in Figure 1. The whole apparatus is deployed in a fume hood equipped with a safety screen. The HPBR consists of a stainless steel pressure cell of $80 \mathrm{~mL}$ internal volume equipped with tempered glass windows (PresSure Products G03XC01B). The windows are placed 180 degrees apart, one illuminated with a $20 \mathrm{~W} 12 \mathrm{~V}$ compact halogen bulb, the other allowing observation with a video camera. The view window diameter is $25 \mathrm{~mm}$. The window diameter is used as a scale for determining droplet and globule diameter sizes. The reactor is equipped with a pressure relief valve (Swagelok R3-A), thermocouple (Omega KMQSS-125G-6), pressure gauge (Swagelok PGI-63B), bleed valve (Swagelok SS-BVM2), and a $3.2 \mathrm{~mm}$ port for admitting $\mathrm{CO}_{2}$ or a mix of $\mathrm{CO}_{2}$ and $\mathrm{H}_{2} \mathrm{~S}$. A cylindrical magnetic stir bar with a cross shape on top (VWR Spinplus) is utilized for internal mixing. Unless otherwise indicated, the experiments were conducted at 2000 psi (13.6 $\mathrm{MPa}$ ) and room temperature, ranging from 15 to $20^{\circ} \mathrm{C}$. The stir bar rotated at $1100 \mathrm{RPM}$.

For preparation of the emulsions, the usual procedure was to introduce a specified amount of pulverized material directly into the open HPBR, followed by a specified volume of de-ionized water. After closing the cap on the HPBR, the remaining volume 
of the HPBR was filled with liquid $\mathrm{CO}_{2}$ or a mix of liquid $\mathrm{CO}_{2}$ and liquid $\mathrm{H}_{2} \mathrm{~S}$ delivered from a syringe pump.

\section{RESULTS}

\subsection{Liquid Carbon Dioxide and Pulverized Limestone}

As reported in previous semi-annual reports, liquid carbon dioxide $\left(\mathrm{ICO}_{2}\right)$ readily forms an emulsion in water when mixed with finely pulverized limestone $\left(\mathrm{CaCO}_{3}\right)$. In Figure 2, a video camera photo is shown of an emulsion of $\mathrm{lCO}_{2}$-in-water stabilized by pulverized limestone. The HPBR contained $55 \mathrm{~mL}$ of de-ionized water, $25 \mathrm{~mL} l \mathrm{CO}_{2}$, and $1.5 \mathrm{~g}$ commercial grade Hubercarb ${ }^{\mathrm{TM}}$ Q6 pulverized limestone. The pressure was 13.6 MPa, temperature $20^{\circ} \mathrm{C}$. All of the $l \mathrm{CO}_{2}$ introduced into the HPBR was emulsified. The resulting globules are heavier than the water they are dispersed in, so they settle in the bottom of the view cell. Apparently, a few $\mathrm{ICO}_{2}$ droplets were not completely sheathed with Q6 particles, so they float at the top of the cell. In order to bring the globules into view of the camera, they were stirred up gently with the magnetic stir bar. The sheathed globules' diameter is in the range of $100-200 \mu \mathrm{m}$.

\subsection{Liquid Acid Gas and Pulverized $\mathrm{CaCO}_{3}$}

For this experiment Sigma-Aldrich reagent grade $\mathrm{CaCO}_{3}$ was used. Scanning Electron Microscopy (SEM) indicated that the $\mathrm{CaCO}_{3}$ particle size is in the $10-15 \mu \mathrm{m}$ range. A liquid acid gas (IAG) mixture was prepared containing $85 \% l \mathrm{CO}_{2}$ and $15 \% \mathrm{lH}_{2} \mathrm{~S}$ by volume. About $65 \mathrm{~mL}$ of de-ionized water, $15 \mathrm{~mL}$ of $\mathrm{lAG}$, and $5 \mathrm{~g}$ of the Sigma-Aldrich $\mathrm{CaCO}_{3}$ were added to the HPBR. The pressure was $10.2 \mathrm{MPa}$, temperature $20^{\circ} \mathrm{C}$. The mixture was stirred with a magnetic stir bar at $1100 \mathrm{rpm}$. The resulting globules are shown in Figure 3. The sheathed globules are heavier than water, so they settled in the bottom of the view cell. They were gently stirred with the stir bar to bring them into view of the digital camera. The globules' diameter is in the $200-300 \mu \mathrm{m}$ range. We noticed in previous experiments that in addition to the shear force imparted by the magnetic stir bar, the particle size is a factor in determining the nascent globule diameter. Evidently, the larger Sigma-Aldrich $\mathrm{CaCO}_{3}$ particles cause larger globule formation compared to the Q6 pulverized limestone.

\subsection{Liquid Acid Gas and Flyash}

A liquid acid gas (lAG) mixture was prepared containing $70 \% l \mathrm{CO}_{2}$ and $30 \% l \mathrm{H}_{2} \mathrm{~S}$ by volume. About $65 \mathrm{~mL}$ of de-ionized water, $15 \mathrm{~mL}$ of $\mathrm{lAG}$, and $5 \mathrm{~g}$ of unprocessed flyash were added to the HPBR. The pressure was $13.6 \mathrm{MPa}$, temperature $20^{\circ} \mathrm{C}$. From SEM analysis, we determined the mean particle size of the flyash as $2.5 \mu \mathrm{m}$. The mixture was stirred with a magnetic stir bar at $1100 \mathrm{rpm}$. The resulting globules are shown in Figure 4. All of the IAG was emulsified. The resulting globules are heavier than the water they are dispersed in, so they settle in the bottom of the view cell. They were gently stirred with the stir bar to bring them into view of the digital camera. The globules' diameter is in the $80-150 \mu \mathrm{m}$ range. 


\subsection{Liquid Acid Gas and Siderite}

A liquid acid gas (lAG) mixture was prepared containing $85 \% l \mathrm{CO}_{2}$ and $15 \% \mathrm{lH}_{2} \mathrm{~S}$ by volume. About $65 \mathrm{~mL}$ of de-ionized water, $15 \mathrm{~mL}$ of $\mathrm{lAG}$, and $5 \mathrm{~g}$ of finely milled siderite $\left(\mathrm{FeCO}_{3}\right)$ were added to the HPBR. The pressure was $13.6 \mathrm{MPa}$, temperature $20^{\circ} \mathrm{C}$. The mixture was stirred with a magnetic stir bar at $1100 \mathrm{rpm}$. The resulting emulsion is shown in Figure 5. In addition to the sheathed globules, excess siderite particles are visible in the frame. It is also possible, although we have not yet confirmed with chemical analysis, that a part of the $\mathrm{lH}_{2} \mathrm{~S}$ reacted with $\mathrm{FeCO}_{3}$ in the aqueous solution to form iron sulfide $(\mathrm{FeS})$ :

$$
\mathrm{FeCO}_{3}+\mathrm{H}_{2} \mathrm{~S} \div \mathrm{FeS}+\mathrm{H}_{2} \mathrm{CO}_{3}
$$

Some of the floating particles visible in Figure 5 may be due to FeS precipitate from reaction (1). If confirmed (which we intend to do in the next semi-annual period), the presence of FeS precipitate may have important implications in regard to lAG disposal in deep geologic formations. Iron minerals, in the form of iron carbonates or iron silicates, are ubiquitous ingredients of the formations. Upon injection into the formations, the $l \mathrm{H}_{2} \mathrm{~S}$ part of the IAG-in-water emulsion, may react with the surrounding iron containing minerals, precipitating the insoluble FeS. This is called mineral trapping. In such a fashion, the injected $l \mathrm{H}_{2} \mathrm{~S}$ may not escape from the formation, reducing the risk of leakage of this toxic material into overlying fresh water aquifers, or re-emergence into the atmosphere.

\section{CONCLUSIONS}

In the past semi-annual project period of this Co-operative Agreement the emphasis has shifted from deep ocean to deep geologic sequestration of carbon dioxide. The same fine particle stabilized emulsions of liquid carbon dioxide-in-water that would be useful for deep ocean sequestration can be applied for sequestration in deep geologic formations. The advantage of injecting a $l \mathrm{CO}_{2}$-water emulsion stabilized by fine particles into geologic formations is that the emulsion is denser than $l \mathrm{CO}_{2}$ alone, thus the injected emulsion may spread horizontally in the formation, rather than buoying upward (fingering) as the low density $\mathrm{ICO}_{2}$ could. (Actually, at the pressure and temperature conditions of the deep geologic formations, $l \mathrm{CO}_{2}$ will convert to supercritical $\mathrm{CO}_{2}$ $\left(s c \mathrm{CO}_{2}\right)$. The latter is less dense than $\mathrm{ICO}_{2}$, so it has a higher buoyancy than the liquid phase.) Cheap and abundant raw materials for fine particles are limestone and sand. However, they have to be milled into very fine particles, in the range of a few micrometers. The economic and energy cost in forming the emulsions lies mainly in milling the raw materials into the fine powder. We also found that unprocessed flyash, collected by electrostatic precipitators at coal-fired power plants, can be used for forming the emulsion. This would incur a negative cost, because most power plants have to pay a price for proper disposal of the flyash that they are generating.

We also have demonstrated that particle stabilized emulsions can be formed with a mixture of liquid carbon dioxide and liquid hydrogen sulfide. The mixture of $\mathrm{CO}_{2}$ and 
$\mathrm{H}_{2} \mathrm{~S}$ is called acid gas (AG). It is a common byproduct of oil and gas exploration. The disposal of AG is a big problem for the oil and gas industry. The injection of liquid AG in the form of a particle stabilized emulsion into deep geologic strata may reduce the risk of AG leaking into overlying fresh water aquifers, or re-emergence into the atmosphere.

\section{PLANS FOR THE NEXT SEMI-ANNUAL PERIOD}

In the next semi-annual period we shall perform further laboratory investigations on the creation of particle stabilized emulsions of liquid carbon dioxide and liquid acid gas for geologic sequestration, namely:

- Testing and evaluation of a static mixer for the production of micro-emulsions of $\mathrm{ICO}_{2}$-in-water and $\mathrm{lAG}$-water using very fine particles as stabilizers.

- Testing and evaluation of a micro-fluidizer for the production of micro-emulsions of $l \mathrm{CO}_{2}$-in-water and $l \mathrm{AG}$-water using very fine particles as stabilizers.

- Preparing the overall Final Report of this Co-operative Agreement, which currently is slated to expire September 30th, 2007. 


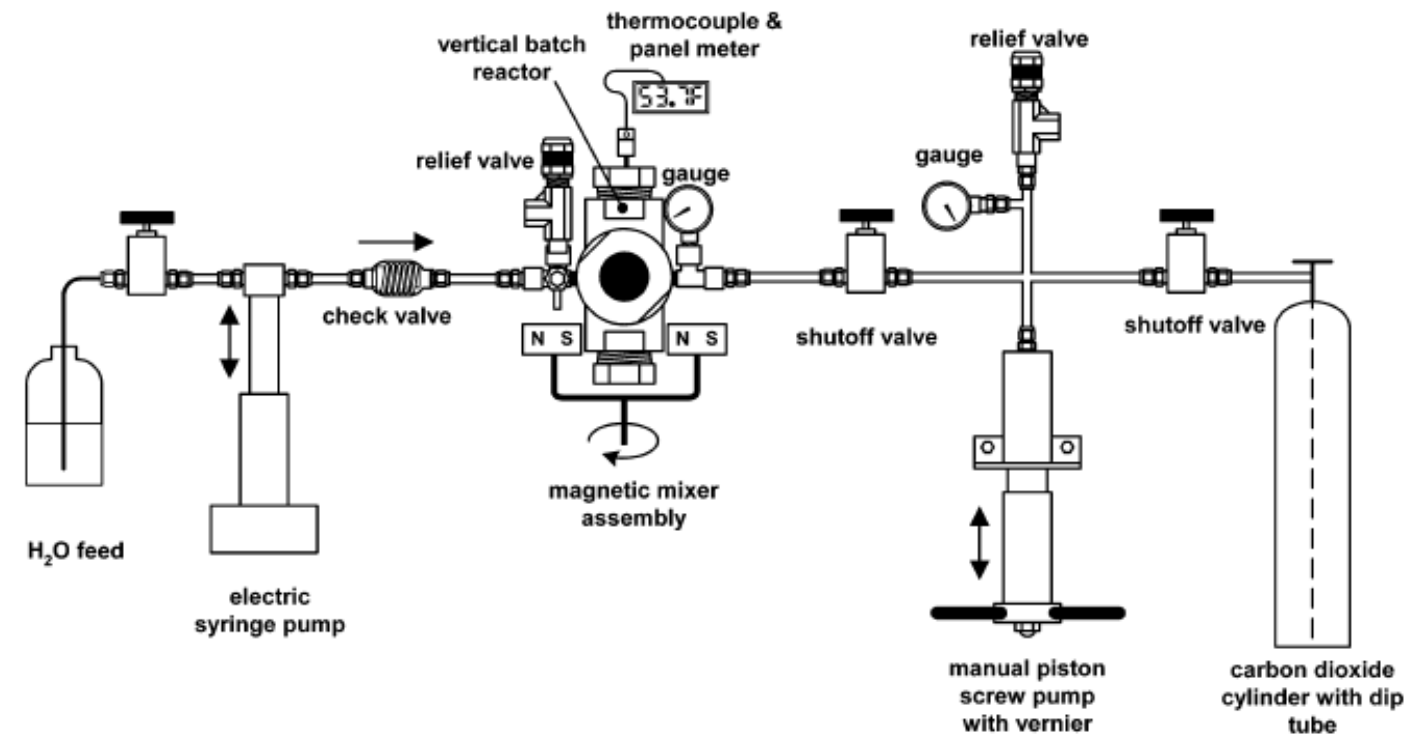

Figure 1. High Pressure Batch Reactor with View Window and Auxiliary Equipment 


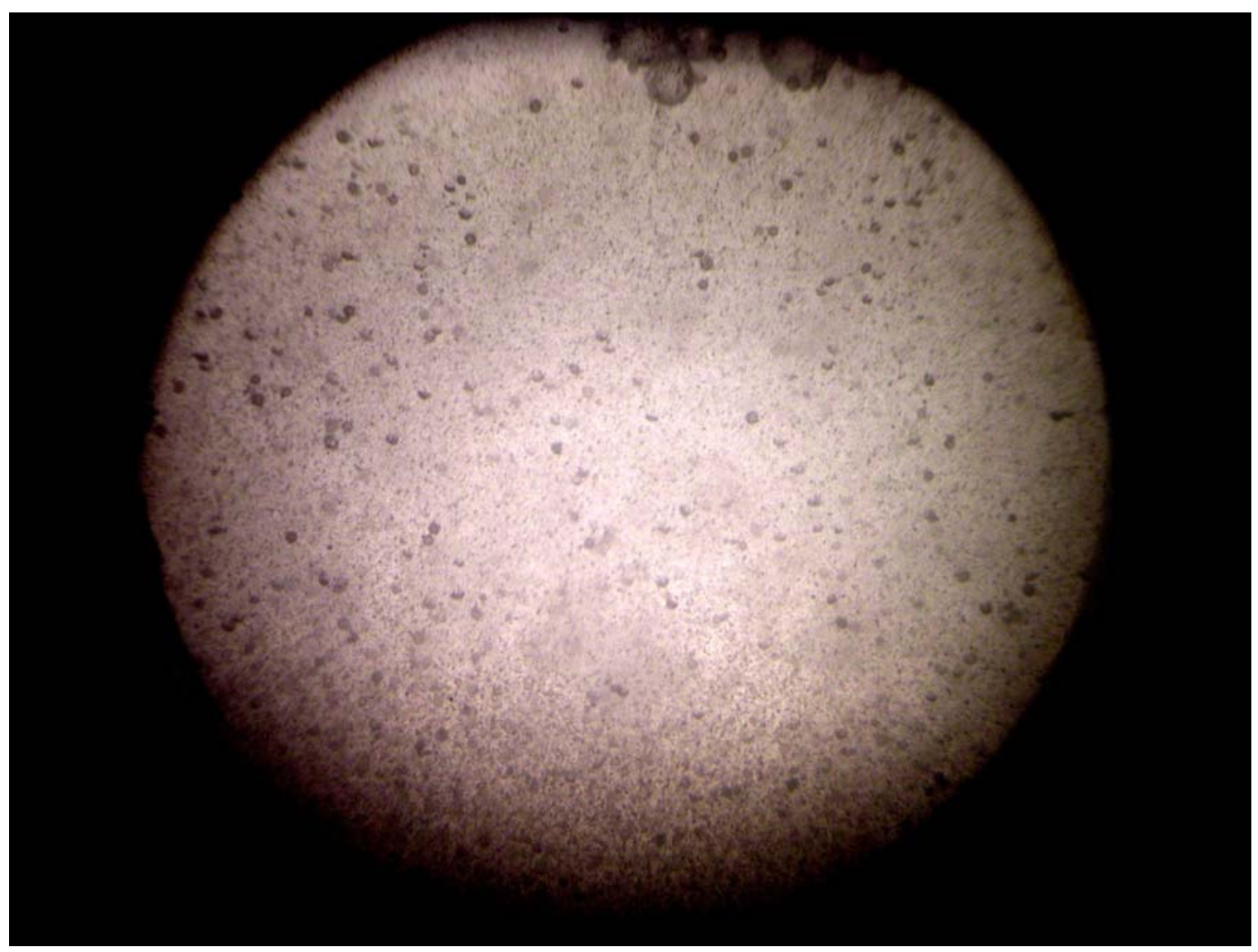

Figure 2. Emulsion of $\mathrm{ICO}_{2}$-in-Water Stabilized with Pulverized Limestone 


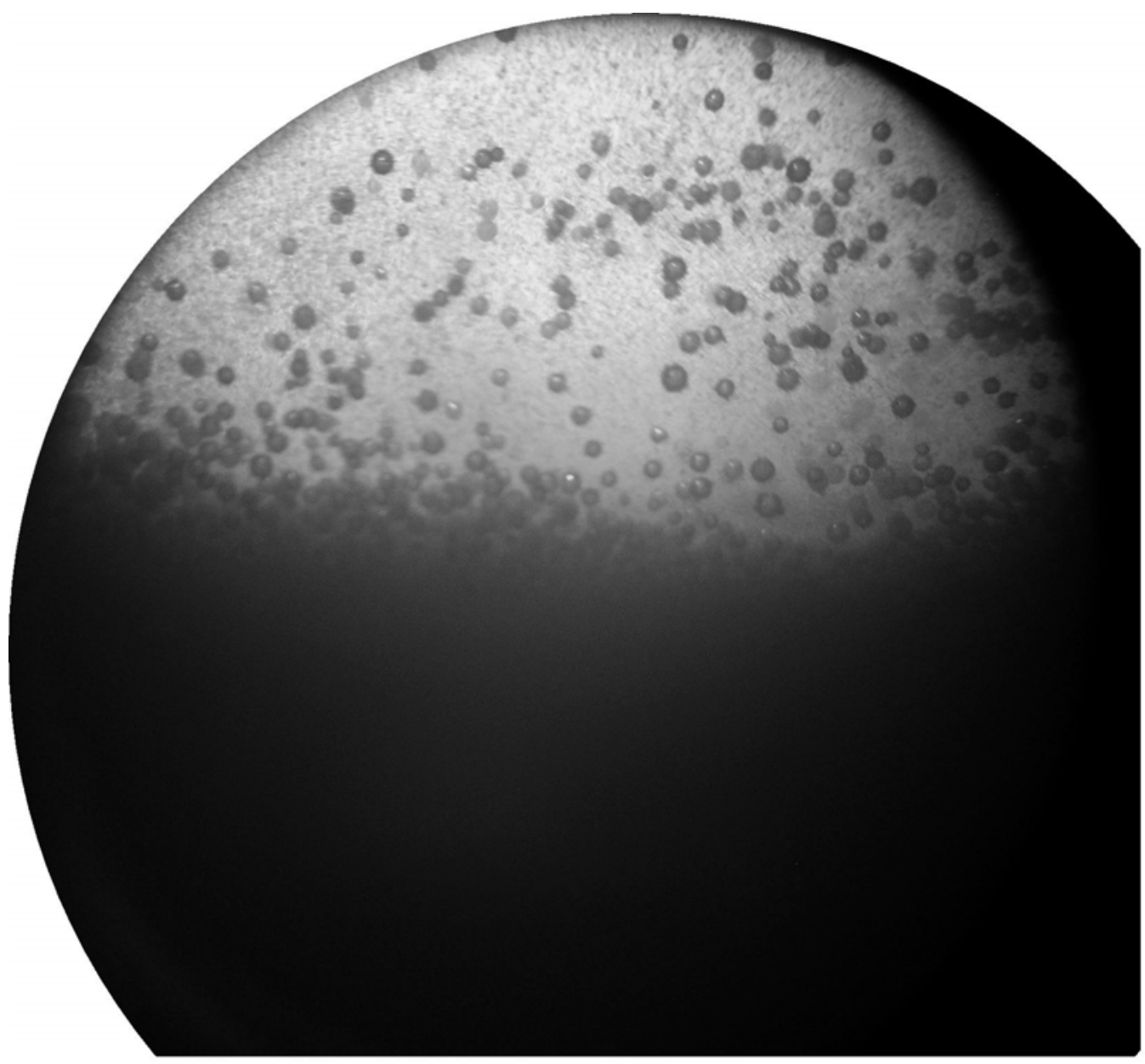

Figure 3. Emulsion of IAG-in-Water Stabilized with Sigma-Aldrich reagent grade $\mathrm{CaCO}_{3}$ 


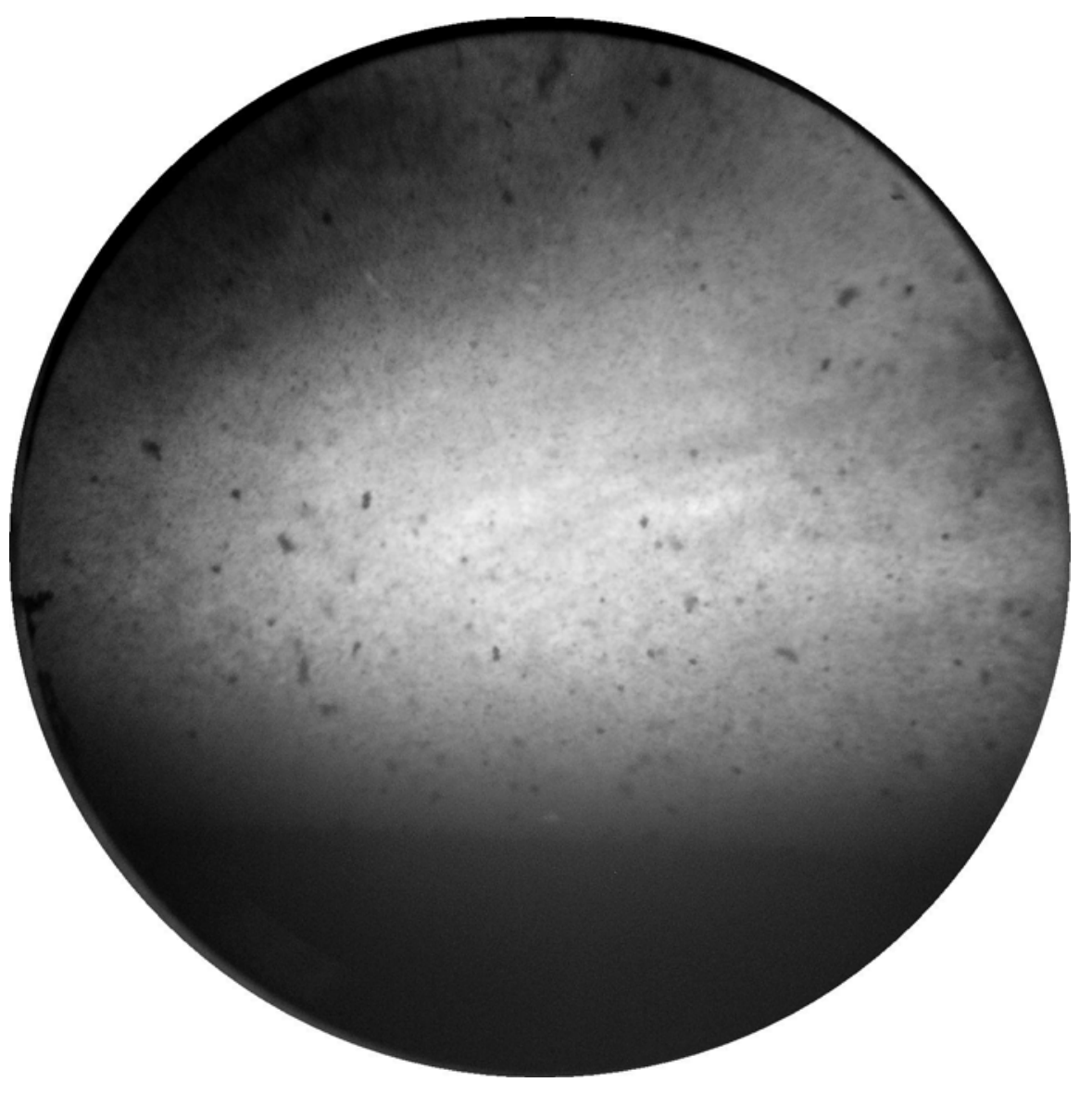

Figure 4. Emulsion of IAG-in-Water Stabilized with Flyash 


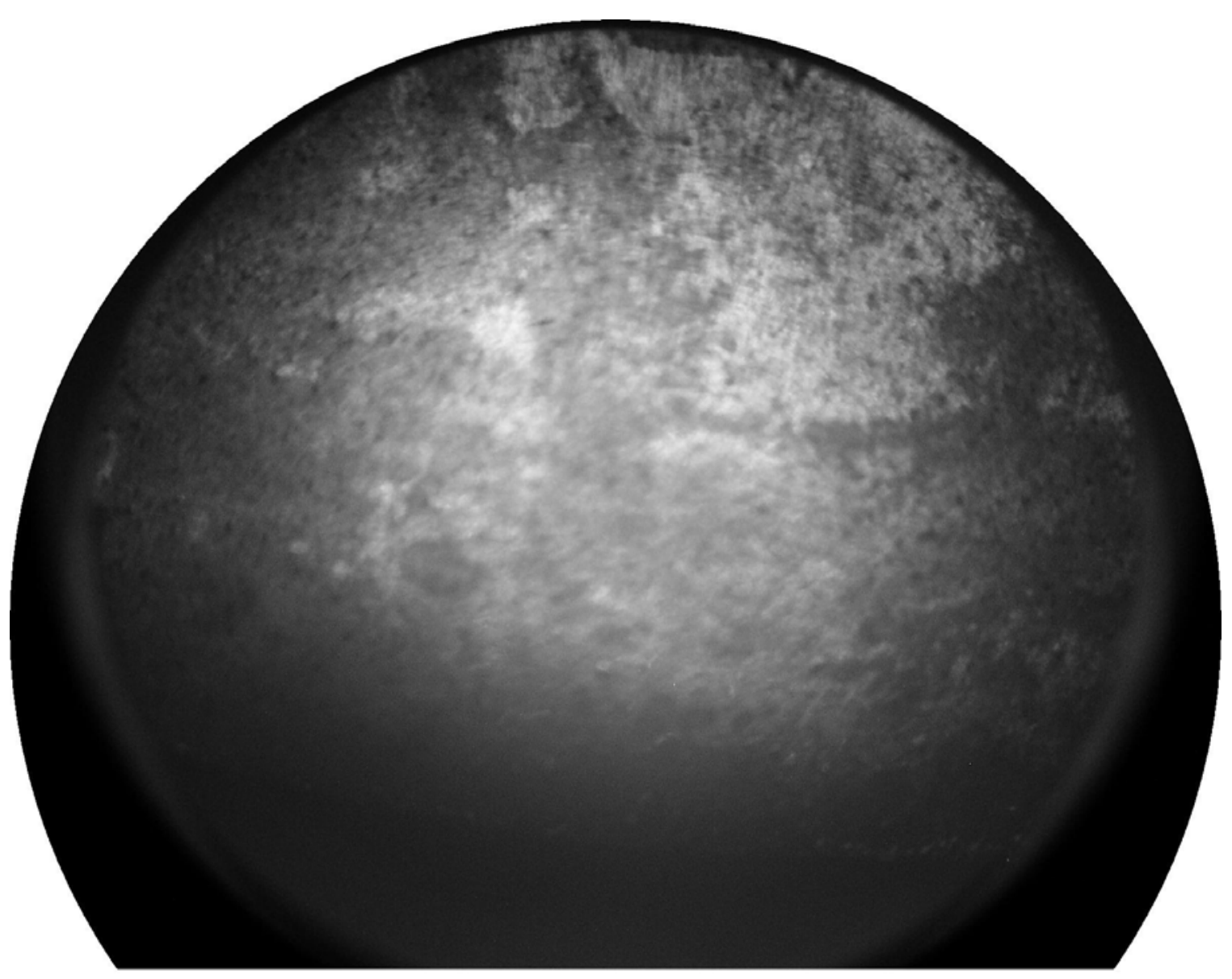

Figure 5. Emulsion of IAG-in-Water Stabilized with Siderite 